\title{
Use of Keratin Present in Chicken Feather as a Hydrogen Storage Material: A Review
}

\author{
Akhil Punneri Madathil, Siddarth Krishnaraja Achar, Vinutha Moses, Ujwal Shreenag Meda, \\ N Chetan, C Vidya, Lourdu Antony Raj and Manjula Sarode
}

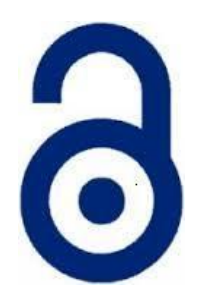

\author{
Received: 12 September 2020 \\ Accepted: 07 October 2020 \\ Published: 20 October 2020 \\ Publisher: Deer Hill Publications \\ (c) 2020 The Author(s) \\ Creative Commons: CC BY 4.0
}

\begin{abstract}
Global warming is the major consequence of pollution. The pollutants that contribute to global warming are commonly known as greenhouse gases. The world has seen an increase in the carbon dioxide concentration over the past few years. The largest sources of carbon emission are the combustion of fossil fuels. The concept of "Green Clean Energy" raised on a mission to reduce the release of these hazardous emissions. Hydrogen is one of those clean energy fuel which helps in solving the present crisis. Materials such as chicken feathers can be used as a medium to store hydrogen. Several research studies are reviewed where chicken feathers are thermally treated by the method of pyrolysis to make them a novel material for hydrogen storage. The uniqueness in the structure and properties of chicken feather is it contains $90 \%$ of keratin fibre when heated increases its micropore volume that results in higher hydrogen uptake.
\end{abstract}

Keywords: Hydrogen, chicken feather, keratin fibre, structure, pyrolysis, clean energy.

\section{INTRODUCTION}

The requirement for energy is rising exponentially day by day, but there is no sufficient conventional source of energy that can support this demand. The conventional energy sources like oil, gas and coal are fossil fuels [1] which deteriorate the environment drastically, burning of them will produce large amounts of greenhouse gases and other pollutants. Carbon dioxide, a major greenhouse gas concentration in the atmosphere has steadily increased to 405.25 ppm in 2016 [2], making 2016, one of the hottest year ever recorded is shown in Figure1 [2, 3]. People are trying to find various solutions to this crisis, one being usage of more clean energy fuels like solar, wind, bio, hydro, geothermal, ocean and hydrogen energy [4].

\subsection{Hydrogen as Energy}

Hydrogen can be generated from clean and green sources and its energy content is very high (120 MJ/kg). This makes hydrogen one of the most potential fuel for the future. Hydrogen can be generated from numerous sources like water (by thermochemical spitting, photovoltaic cell and photo chemical reaction), glycerol, biomass and other sources (urea, electrohydrogenesis from organic material, cheese whey, hydrogen sulphide) [5]. There are also several disadvantages of hydrogen like, its low energy density (high pressure has to be applied to store large mass of hydrogen in a small space), its difficulty in liquefaction (temperature less than 22 Kelvin), its high flammability, hydrogen embrittlement (when stored in a high pressure steel tank) [6]. The liquefied hydrogen or pressurized hydrogen (above $35 \mathrm{MPa}$ ) has densities that are 10 and 30 times lower than the ambient gasoline density [8]. Hydrogen can be stored in numerous ways like compression, liquefaction, physio sorption in microporous carbon, metallic hydride and complex hydrides [7].

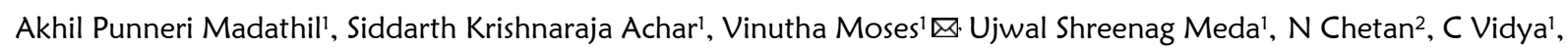
Lourdu Antony Raj' and Manjula Sarode ${ }^{1}$

'Department of Chemical Engineering, Rashtreeya Vidhyalaya College of Engineering

Bengaluru-560059, India

2Department of IEM, Dr Ambedkar Institute of Technology

Bengaluru-560056, India

E-mail: vinuthamoses@rvce.edu.in

Reference: Akhil Punneri Madathil, Siddarth Krishnaraja Achar, Vinutha Moses, Ujwal Shreenag Meda, N Chetan, C Vidya, Lourdu Antony Raj and Manjula Sarode (2020). Use of Keratin Present in Chicken feather as a Hydrogen Storage Material: A Review. International Journal of Engineering Materials and Manufacture, 5(4), 148-155. 


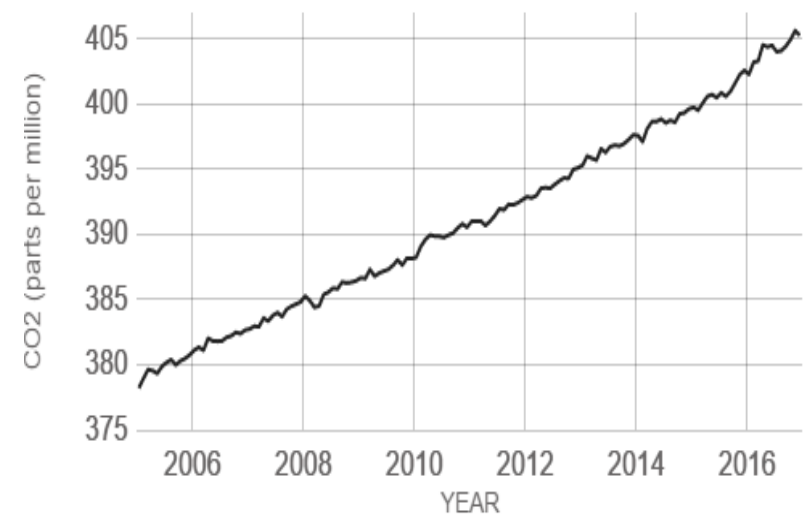

Figure 1: Concentration change in $\mathrm{CO}_{2}$ over a timespan [2].

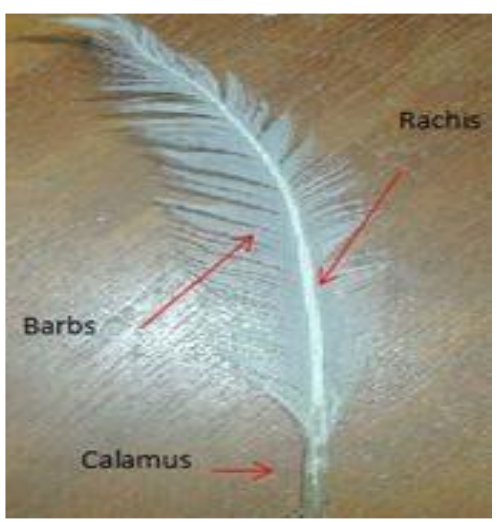

Figure 2: Parts of chicken feather [12]

The various microporous carbon materials are carbon nanotubes, activated carbon, graphite, carbon nanofibers and metal organic framework. One of the prominent methods in physio sorption is usage of chicken feathers as carbon source. This material is highly porous and has high surface area which contributes to higher physio sorption [8]. Major component of chicken feather is keratin which helps in trapping the hydrogen gas. Keratin when heated hardens and it attains a structure comparable to carbon nanotubes. The amount of hydrogen stored in keratin is similar to that of expensive carbon nanotubes [9]. Several tons of keratin waste are produced annually from poultry farm making their disposal very tedious. Various reducing agents are used to chemically treat these waste chicken feathers, they are also degraded chemically and physically by $\mathrm{NaOH}$ and heat treatment [10].

\subsection{Structure of Chicken Feather}

Poultry feathers are a cheap and renewable source of fibre that contain about $90 \%$ keratin protein [12]. Statistics show that every year the world produces more than 4 billion pounds of chicken feather [14]. The uniqueness in the structure and properties of chicken feather makes them preferable for several applications like textile products, films, composites and energy storage source [16]. The density of chicken feathers is about $0.8 \mathrm{~g} / \mathrm{cm}^{3}$ which is lower than other sources of fibre such as cellulose $\left(1.5 \mathrm{~g} / \mathrm{cm}^{3}\right)$ fibre and wool $\left(1.3 \mathrm{~g} / \mathrm{cm}^{3}\right)$. Their low density, high mechanical strength, hydrophobicity, high flexibility and structural interaction with other fibres helps to develop new products of very rare and unique properties contrary to natural or synthetic fibres $[12,13]$.

The chicken feather consists of three primary units. The rachis (about $7 \mathrm{~cm}$ in length) forms the central axis. This central axis is attached to the Calamus (present at the base). The secondary structure consists of barbs which are attached to the rachis. Their length varies along the central axis (from 1 to $4.5 \mathrm{~cm}$ ). Barbs are usually longer at the base and shorter toward the tip, as shown in Figure 2. The keratin has $\beta$-pleated and $\alpha$-helix sheet structure as shown in Figure 3 that includes about 20 amino acids, mainly of cysteine. Its structure consists of a central carbon linked to functional groups (amine, $-\mathrm{NH}_{2}$, and carboxylic acid, $-\mathrm{COOH}$ ), the hydrogen atoms and the group $\mathrm{R}$ (sulphur) [15].

By "slow pyrolysis" and other chemical treatment methods, the properties of chicken feathers can be improved and modified. Slow pyrolysis is one of the heat treatments well known and commonly used to obtain carbon in a controlled monitored environment, time, and temperature. During this process volatile components from carbonaceous material are released. These organic substances are a waste in the form of $\mathrm{CO}_{2}$ are returned to the environment [17].
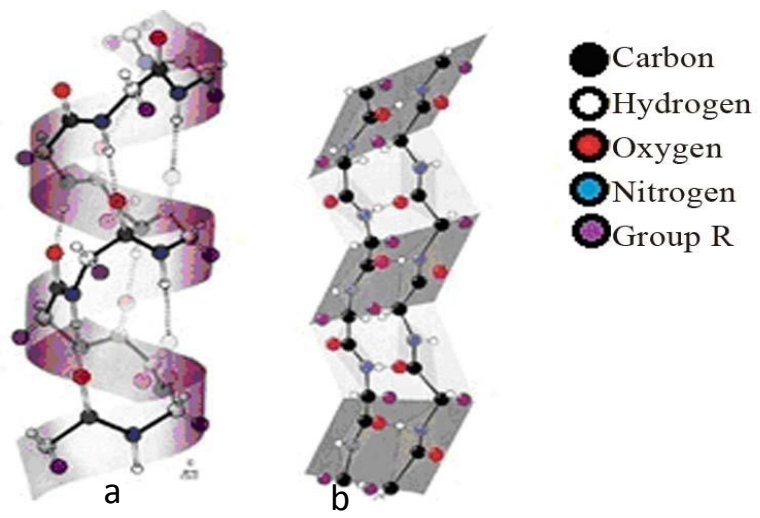

Figure 3: (a) $\alpha$-helix and (b) $\beta$-pleated Sheet structure [16]. 


\section{MATERIALS, EQUIPMENT AND SAMPLES PREPARATION}

There are several thermo-chemical processes such as gasification, combustion, hydrogenation, liquefaction and pyrolysis which are used to convert the raw material into energy products. Pyrolysis method of conversion is important since they convert the raw materials directly into solid, liquid, gaseous products by thermal decomposition in the absence of oxygen. There are three broad methods of pyrolysis- slow, intermediate and fast. Slow pyrolysis is incorporated to process the chicken feather because it leads to less liquid and gaseous product and more of char production [18]. The keratin fibres present in the chicken feathers forms cross-links when heated which strengthens its structure and enhances its porosity thereby increasing the surface area. Chicken feathers are obtained from various sources like poultry farms and they are separated into rachis and ramus. The general process of pyrolysis of chicken feather proposed by Richard P. Wool et al. [19].is as shown in Figure 4.

Iliana Giraldo et al. (2013) [9], cleaned the rachis chicken feather and dried them at temperature $50^{\circ} \mathrm{C}$ and chopped into fine lengths. The chopped pieces were heated at $250^{\circ} \mathrm{C}, 350^{\circ} \mathrm{C}$ and $450^{\circ} \mathrm{C}$ for 24 hours in nitrogen atmosphere. The resulting activated carbon was filtered using the mesh of size 0.27-0.55 mm and dried for 24 hours at $105^{\circ} \mathrm{C}$. The sample was again heated at a rate of $5^{\circ} \mathrm{C} / \mathrm{min}$ in nitrogen atmosphere from room temperature to final activation temperature. Distilled water was used to wash the activated carbon till a constant $\mathrm{pH}$ value is obtained.

Erman Senoz et al. (2009) [20], obtained chicken feathers that were already separated from the quill. The pyrolysis was conducted in a Thermolyne Type F6000 box furnace with a capacity of 861 in $^{3}$ with a constant nitrogen flow for 3 hours to get pyrolysed chicken feather fibre (PCFF). The samples were heated in a two different ways. The first five samples were isothermally heated at a rate of $3^{\circ} \mathrm{C} / \mathrm{min}$ to $215^{\circ} \mathrm{C}$ for $2,4,10,15$ and 24 hours respectively as shown in Table 1 and the variation in residue fraction is as shown in Figure 5.

The next six samples were pyrolysed in a two-step process, Firstly, heated at a low temperature at $215^{\circ} \mathrm{C}$ or $220^{\circ} \mathrm{C}$ for a desired time and a constant rate $\left(3^{\circ} \mathrm{C} / \mathrm{min}\right)$. Later these samples were again heated to a higher temperature $\left(400^{\circ} \mathrm{C}, 450^{\circ} \mathrm{C}\right.$ or $500^{\circ} \mathrm{C}$ ) for an hour. There were two more samples that were heated at $400^{\circ} \mathrm{C}$ for 1 hour and $220^{\circ} \mathrm{C}$ for 24 hours respectively as shown in Table 2 . The graph generated from the available data of residue fraction is shown in the Figure 6.
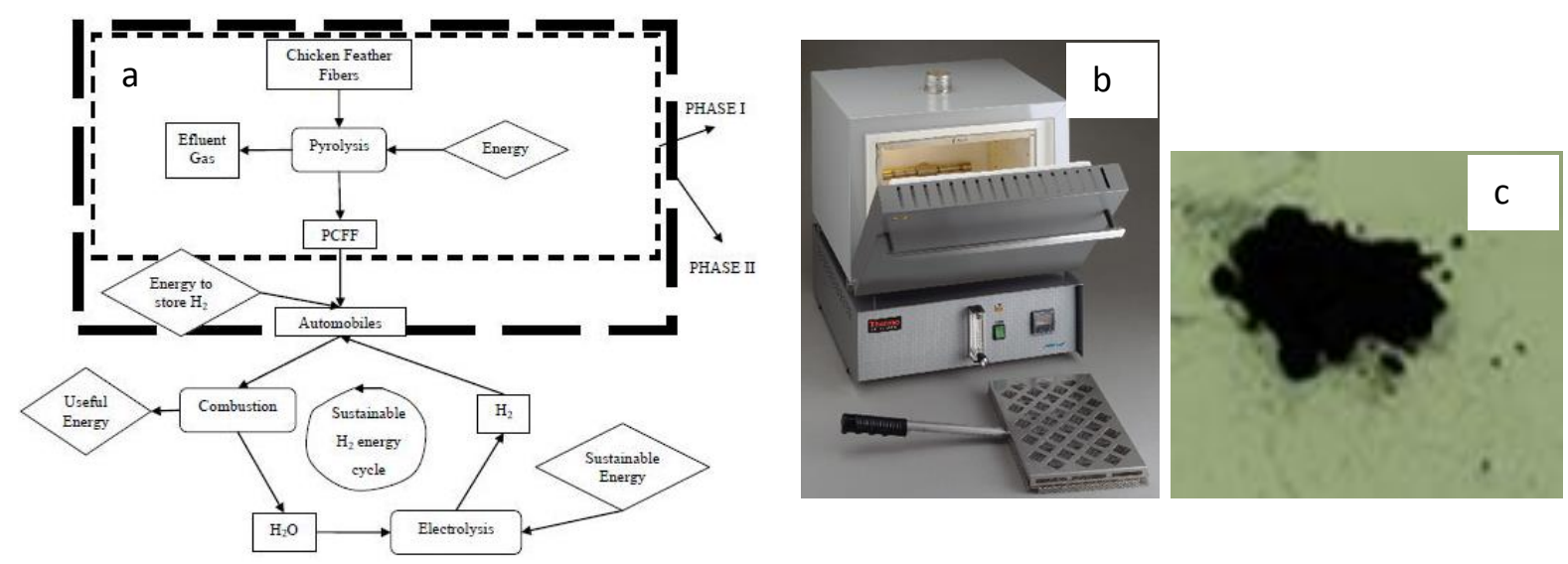

Figure 4: (a) Overall pyrolysis process proposed by Richard P. Wool et al. [19], (b) Thermolyne Type F6000 box furnace [21], (c) Pyrolysed chicken feather [22].

Table 1: Single step pyrolysis at Constant Temperature and varying time [20].

\begin{tabular}{ccccc}
\hline $\begin{array}{c}\text { Sample } \\
\text { PCFF- }\end{array}$ & $\begin{array}{c}\text { Temperature } \\
{ }^{\circ} \mathbf{C} \mathbf{~ i}\end{array}$ & $\begin{array}{c}\text { Rate } \\
{ }^{\circ} \text { C/min }\end{array}$ & $\begin{array}{c}\text { Time } \\
\text { hour }\end{array}$ & Residue fraction \\
\hline 1 & 215 & 3 & 2 & $0.767 \pm 0.019$ \\
\hline 2 & 215 & 3 & 4 & $0.722 \pm 0.012$ \\
\hline 3 & 215 & 3 & 10 & $0.638 \pm 0.016$ \\
\hline 4 & 215 & 3 & 15 & $0.626 \pm 0.011$ \\
\hline 5 & 215 & 3 & 24 & $0.601 \pm 0.015$ \\
\hline
\end{tabular}


Table 2: The pyrolysis parameter with adsorption capacity [20].

\begin{tabular}{|c|c|c|c|c|c|c|c|c|}
\hline $\begin{array}{c}\text { Sample } \\
\text { PCFF- }\end{array}$ & Rate-1 ${ }^{\circ} \mathrm{C} / \mathrm{min}$ & $\begin{array}{l}\mathrm{T}_{1} \\
{ }^{\circ} \mathrm{C}\end{array}$ & $\begin{array}{c}t_{1} \\
\text { hour }\end{array}$ & $\begin{array}{l}\text { Rate-2 }{ }^{\circ} \mathrm{C} \\
/ \mathrm{min}\end{array}$ & $\begin{array}{l}\mathrm{T}_{2} \\
{ }^{\circ} \mathrm{C}\end{array}$ & $\begin{array}{l}t_{2} \\
\text { hour }\end{array}$ & Residue fraction & $\begin{array}{l}\text { Adsorption } \\
\text { capacity }\end{array}$ \\
\hline 6 & 3 & 215 & 24 & 3 & 400 & 1 & $0.176 \pm 0.015$ & Best \\
\hline 7 & 3 & 220 & 24 & 2 & 450 & 1 & $0.101 \pm 0.020$ & Best \\
\hline 8 & 3 & 220 & 32 & 2 & 450 & 1 & $0.063 \pm 0.010$ & Best \\
\hline 9 & 3 & 400 & 1 & - & - & - & $0.209 \pm 0.007$ & Medium \\
\hline 10 & 3 & 220 & 5 & 3 & 400 & 1 & $0.212 \pm 0.018$ & Best \\
\hline 11 & 3 & 215 & 24 & 3 & & & & Low \\
\hline 12 & 3 & 220 & 26 & 2 & & & $0.004 \pm 0.001$ & Medium \\
\hline 13 & 3 & 220 & 24 & - & & & $0.617 \pm 0.022$ & Low \\
\hline
\end{tabular}

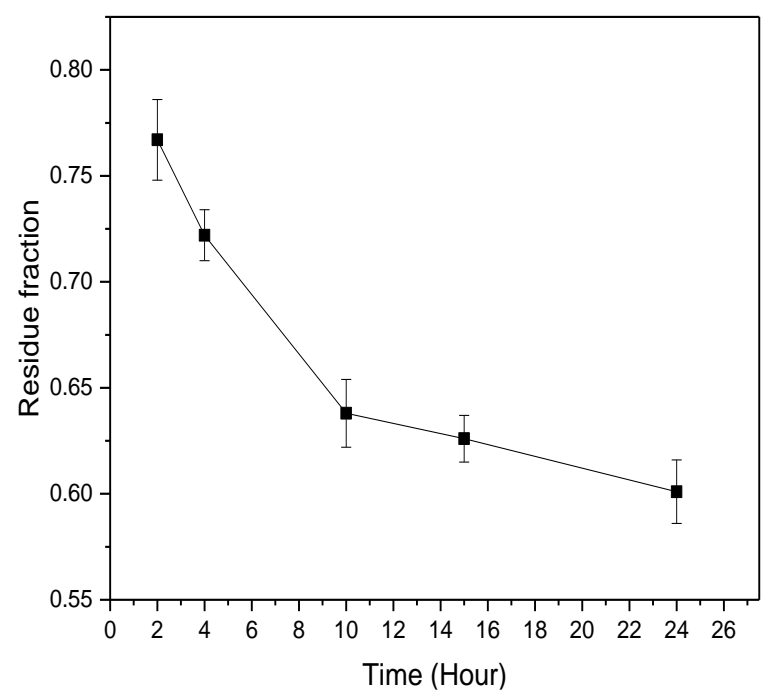

Figure 5: Residue mass fraction of PCFF samples prepared at various time duration.

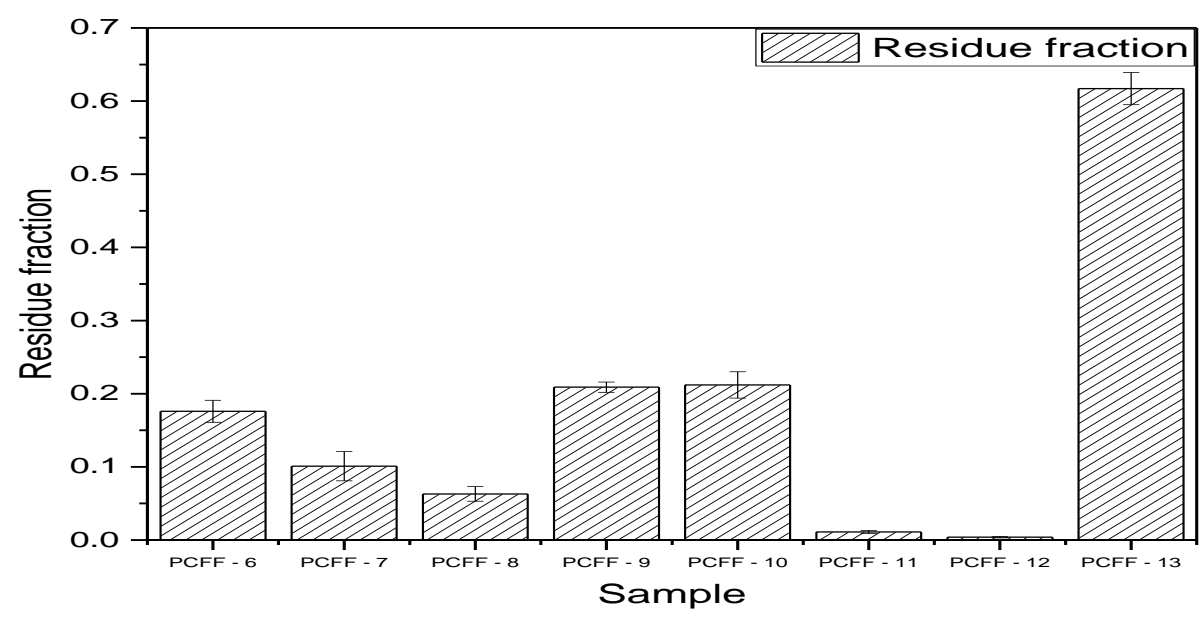

Figure 6: Residue fractions for different samples.

Erman Senoz et al. (2010) [8], prepared PCFF in two step pyrolysis similar to that described earlier. All the samples were heated to $215^{\circ} \mathrm{C}$ at a rate of $3^{\circ} \mathrm{C} / \mathrm{min}$ for 15 hours. The samples were further heated immediately to various isothermal temperatures of $350^{\circ} \mathrm{C}, 400^{\circ} \mathrm{C}, 420^{\circ} \mathrm{C}, 450^{\circ} \mathrm{C}, 500^{\circ} \mathrm{C}$ at a rate of $3^{\circ} \mathrm{C} / \mathrm{min}$ for $0.5,1,1.5$ or 2 hours. The residue fractions of various samples are shown in Figure 7. The cooled fibres, were washed with toluene and water to clean the materials from depositions. 


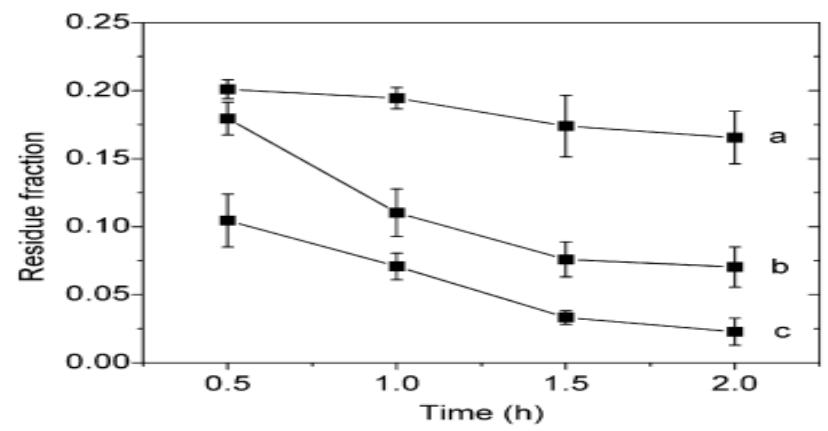

Figure 7: Residue mass fractions of PCFF samples prepared at (a) $400^{\circ} \mathrm{C}$, (b) $420^{\circ} \mathrm{C}$ and (c) $450^{\circ} \mathrm{C}$ versus the pyrolysistime at the 2 nd step.

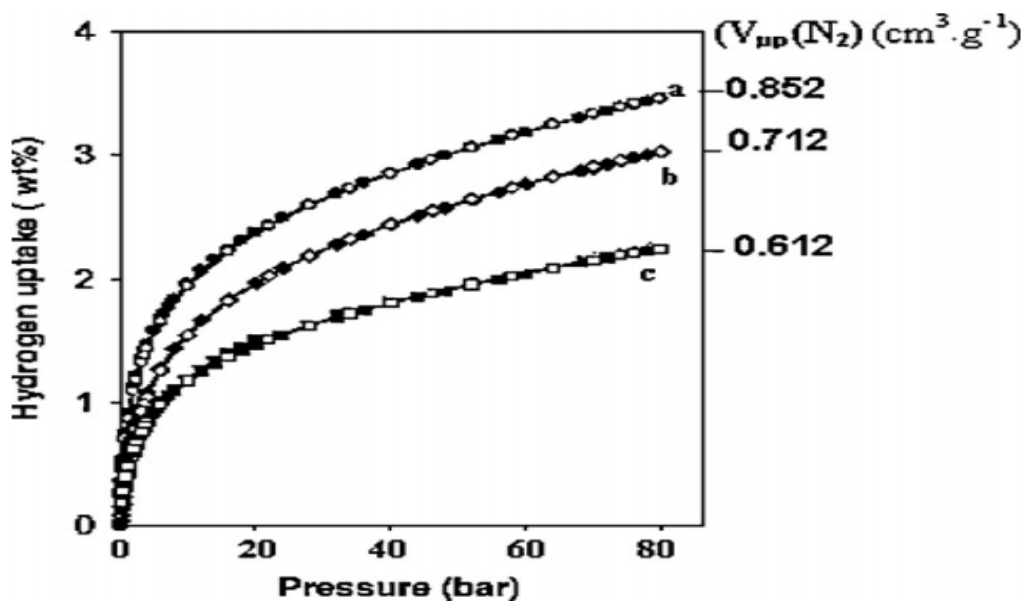

Figure 8: Hydrogen uptake isotherms at $-196^{\circ} \mathrm{C}$ of activated carbons obtained from rachis chicken feathers (a) CFAC-450 (b) CFAC-350 (c) CFAC-250.

\section{Hydrogen Uptake}

Liliana Giraldo et al. (2013) [9] subjected the samples (treated at $250^{\circ} \mathrm{C}, 350^{\circ} \mathrm{C}$ and $450^{\circ} \mathrm{C}$ ) at a constant temperature of $-196^{\circ} \mathrm{C}$ for pressures varying from $20-80$ bar and its hydrogen uptake was measured and plotted as shown in Figure 8. It is understood from the observation that the samples treated at a lower temperature of $250^{\circ} \mathrm{C}$ and $350^{\circ} \mathrm{C}$ showed less hydrogen adsorption capacities which was due to the result of less porosity and surface area. The sample that was treated at $450^{\circ} \mathrm{C}$ showed highest hydrogen uptake with a maximum uptake of $3.5 \mathrm{wt} \%$ at 80 bar. There was an increase in the micropore volume $\left(V_{\mu p}\left(N_{2}\right) \mathrm{cm}^{3} / \mathrm{g}\right)$ with increase in pressure. The sample prepared at $450^{\circ} \mathrm{C}$ showed highest micropore volume.

Erman Senoz et al. (2009) [20], performed nitrogen adsorption, BET analysis and t-plot method on the samples and concluded that the samples that were heated up to $400^{\circ} \mathrm{C}$ and $450^{\circ} \mathrm{C}$ (PCFF-6, 7, 8 and 10) in second pyrolysis step showed higher surface areas and degree of microporosity. Specific surface area ( $S_{\text {BET }}$ ) obtained by BET method [23] in the relative pressure range of $0.01-0.05$ and micropore volume $\left(V_{\text {mic }}\right)$ calculated by t-plot are tabulated in

Table 3: Variation of specific surface area, micropore volume and adsorption capacity for different samples.

\begin{tabular}{cllll}
\hline $\begin{array}{c}\text { Sample } \\
\text { PCFF- }\end{array}$ & S $_{\text {BET }}\left(\mathrm{m}^{2} / \mathrm{g}\right)$ & $\mathrm{V}_{\text {mic }}\left(\mathrm{cm}^{3} / \mathrm{g}\right)$ & $\begin{array}{l}\text { Adsorption } \\
\text { capacity }\end{array}$ & Residue fraction \\
\hline 6 & $436 \pm 4$ & 0.178 & Best & $0.176 \pm 0.015$ \\
\hline 7 & $460 \pm 2$ & 0.196 & Best & $0.101 \pm 0.020$ \\
\hline 8 & $419 \pm 6$ & 0.176 & Best & $0.063 \pm 0.010$ \\
\hline 9 & $376 \pm 0$ & 0.133 & Best & $0.209 \pm 0.007$ \\
\hline 10 & $189 \pm 6$ & 0.072 & Medium & $0.212 \pm 0.018$ \\
\hline 11 & $114 \pm 0$ & 0.041 & Medium & \\
\hline 12 & $14 \pm 0$ & 0.002 & Low & $0.004 \pm 0.001$ \\
\hline 13 & $<1$ & $<0.001$ & Low & $0.617 \pm 0.022$ \\
\hline
\end{tabular}


Erman Senoz et al. (2010) [8], performed nitrogen adsorption, BET analysis and t-plot method on the samples. It is found that, after the second step of pyrolysis the complex nature of the protein resulted in numerous degradations and rearrangement reactions at high temperatures. This is due to the side chain of various amino acids such as cysteine (thiol), serine (hydroxyl), glutamic acid (carboxyl), proline (nonpolar hydrocarbon), arginine (amine), etc. This meant that the evolution of the structure of these fibres during pyrolysis have high sensitivity to the reaction conditions.

There were two divisions of pyrolysis reactions within temperature range $400-450^{\circ} \mathrm{C}$ which are microporeformation and micropore-destroying reaction. From the experimental data as shown in Table 4, it is observed that the maximum specific surface area and microporosity occurs at 1 hour which are plotted in Figure 9 and Figure 10respectively. When the fibre was pyrolysed for a longer time ( $>1$ hour) micropore-destroying reaction predominates decreasing the micropore volume. When hydrogen storage uptake is measured at room temperature and pressure 5.4 $\mathrm{MPa}$ it was evident that pyrolyzing for 1 hour leads to highest hydrogen storage uptake as shown in Figure 11.

Table 4: Variation of hydrogen storage uptake $\left(22^{\circ} \mathrm{C}\right.$ and $\left.5.4 \mathrm{MPa}\right)$, specific surface area and micropore volume according to pyrolysis temperature and time.

\begin{tabular}{lllll}
\hline $\begin{array}{l}\text { Temperature } \\
\text { of Pyrolysis } \\
{ }^{\circ} \mathrm{C}\end{array}$ & $\begin{array}{l}\text { Pyrolysis } \\
\text { time } \\
\mathrm{h}\end{array}$ & $\begin{array}{l}\text { Specific surface area } \\
\mathrm{m}^{2} / \mathrm{g}\end{array}$ & $\begin{array}{l}\text { Micropore } \\
\text { Volume } \\
\mathrm{cm}^{3} / \mathrm{g}\end{array}$ & $\begin{array}{l}\text { Hydrogen storage uptake } \\
\text { at room temperature } \\
\mathrm{wt} \%\end{array}$ \\
\hline 400 & 0.5 & $<10$ & 0.002 & 0.04 \\
\hline 400 & 1 & 414 & 0.178 & 0.35 \\
\hline 400 & 1.5 & 226 & 0.092 & 0.18 \\
\hline 400 & 2 & 51 & 0.020 & 0.22 \\
\hline 420 & 0.5 & 221 & 0.082 & 0.14 \\
\hline 420 & 1 & 315 & 0.120 & 0.25 \\
\hline 420 & 1.5 & 163 & 0.077 & 0.19 \\
\hline 420 & 2 & 237 & 0.092 & 0.24 \\
\hline 450 & 0.5 & 336 & 0.136 & 0.26 \\
\hline 450 & 1 & 430 & 0.173 & 0.37 \\
\hline 450 & 1.5 & 29 & 0.009 & 0.15 \\
\hline 450 & 2 & 89 & 0.032 & 0.20 \\
\hline
\end{tabular}

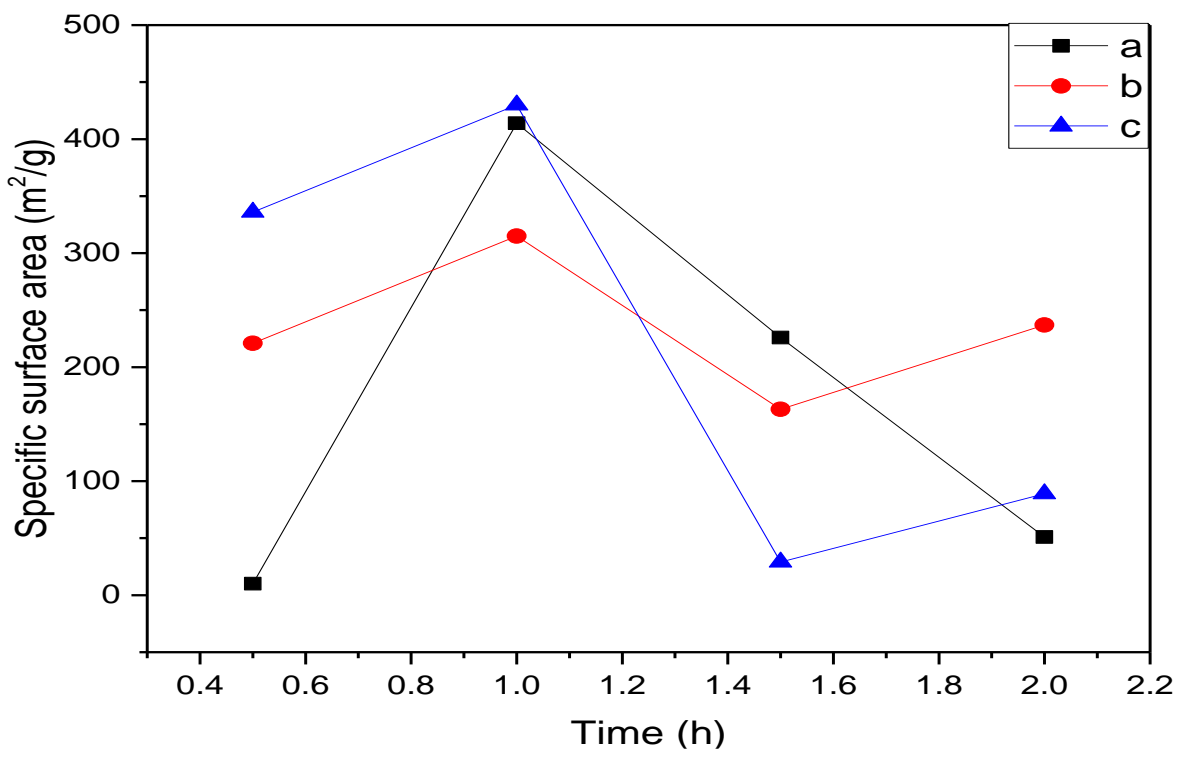

Figure 9: Plot of specific surface area against time for the samples prepared at (a) $400^{\circ} \mathrm{C}$, (b) $420^{\circ} \mathrm{C}$ and (c) $450^{\circ} \mathrm{C}$ at the second step. 


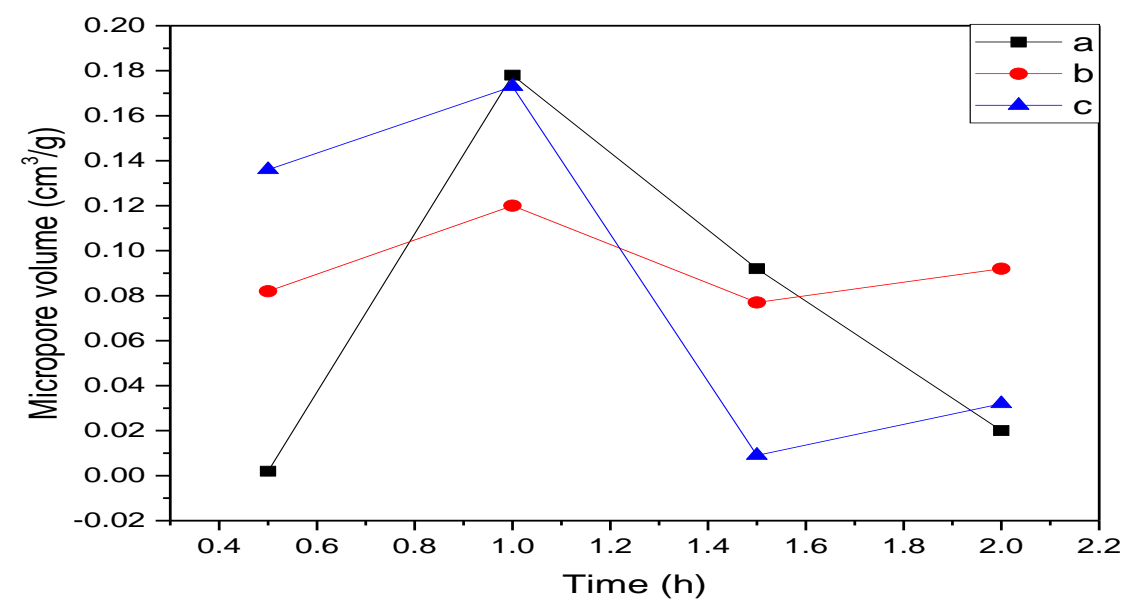

Figure 10: Plot of micropore volume against time for the samples prepared at (a) $400^{\circ} \mathrm{C}$, (b) $420^{\circ} \mathrm{C}$ and (c) $450^{\circ} \mathrm{C}$ at the second step.

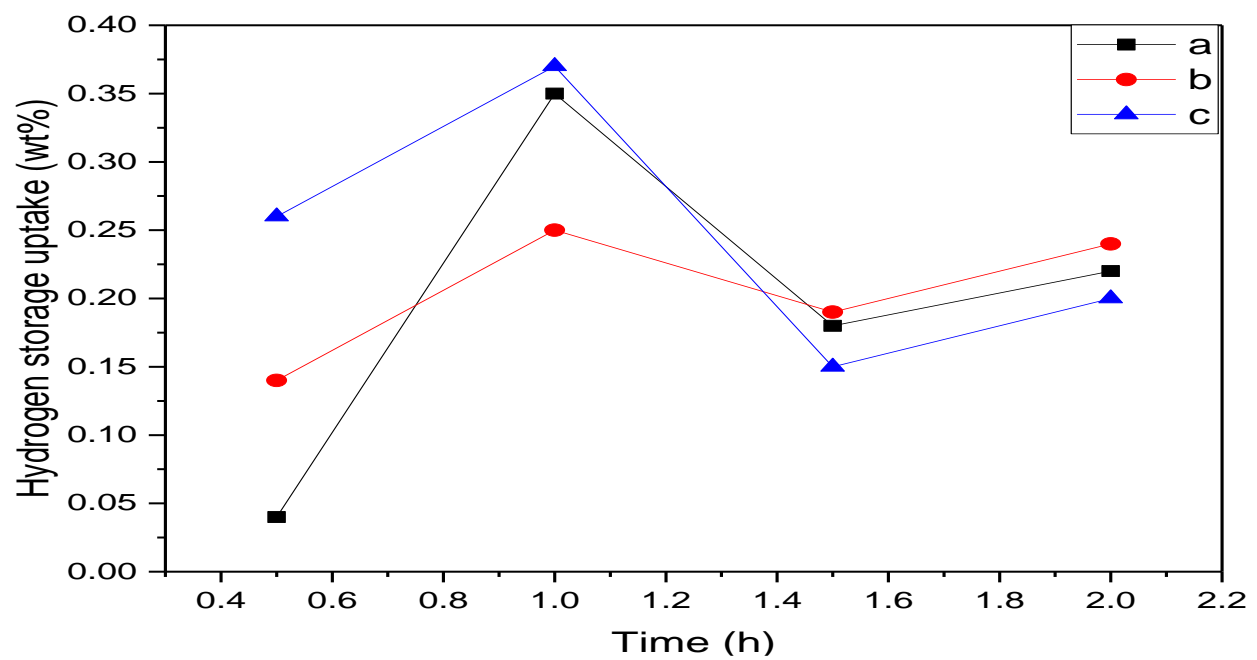

Figure 11: Plot of hydrogen storage uptake at room temperature $\left(22^{\circ} \mathrm{C}\right)$ and pressure $5.4 \mathrm{MPa}$ against time for the samples prepared at (a) $400^{\circ} \mathrm{C}$, (b) $420^{\circ} \mathrm{C}$ and (c) $450^{\circ} \mathrm{C}$ at the second step.

\section{Conclusions}

1. When the chicken feathers were treated less than an hour, the pyrolysed substance showed lesser micropore volume that led to the decrease in hydrogen uptake.

2. Research studies and experiments have shown highest hydrogen uptake for one hour of treatment in the temperature range $400-450^{\circ} \mathrm{C}$.

3. Hydrogen storage increases with increase in microporosity.

\section{REFERENCES}

1. http:// www.environmentalleader.com category/conventional-energy/

2. http://www.climate.nasa.gov/vital-signs/carbon-dioxide/

3. https://www.nasa.gov/feature/goddard/2016/climate-trends-continue-to-break-records/

4. Das S, Sikdar S (2016). A Review on the Non-conventional Energy Sources in Indian Perspective IJERT

5. Dutta $S$ (2016). A review on production, storage of hydrogen and its utilization as an energy resource. Journal of Industrial and Engineering Chemistry, 20(4).1148-56.

6. Larminie J, Dicks A, McDonald MS (2003). Fuel cell systems explained. Chichester, UK: J. Wiley.

7. Zhou L (2005) Progress and problems in hydrogen storage methods. Renewable and Sustainable Energy Reviews, 9(4):395-408. 
8. Senoz E, Wool RP (2011). Hydrogen storage on pyrolyzed chicken feather fibers. International journal of hydrogen energy, 36(12), 7122-7.

9. Giraldo L, Moreno-Piraján JC (2013). Exploring the use of rachis of chicken feathers for hydrogen storage. Journal of Analytical and Applied Pyrolysis, 104, 243-8.

10. Kovács, Balázs Bálint. Zoltán Bagi. András Tóth .Gábor Rákhely. Katalin Perei. Kornél L (2005).Utilization of keratin-containing biowaste to produce biohydrogen. Applied Microbiology Biotechnology, 69,404-410.

11. Barone, J.R. and Schmidt (2005), W.F. Polyethylene reinforced with keratin fibers obtained from chicken feathers. Composites Science and Technology, 65(2), 173-181.

12. Jones LN, Riven DE, Tucker DJ. Handbook of fiber chemistry.Marcel Dekker, Inc., New York, 1998.

13. Belarmino, D.D., Ladchumananandasivam, R., Belarmino, L.D., Andrade, S.M.B., Galvão, A.O. and Ribeiro, L.M. (2012). Study of thermal stability of keratin fibre $(\mathrm{kf})$ of chicken feathers for obtaining of carbon carbonised feathers (cf).Holos, 12, 30-40.

14. CampbellM.K.Bioquímica, 3th Edition, Artes MedicasSul-Sul/Biomed, 2006.

15. Martínez-Hernández AL, Velasco-Santos C. Keratin fibers from chicken feathers: structure and advances in polymer composites. Keratin: Structure, Properties and Applications: 1, 49-211.

16. Meyers MA, Chen PY, Lin AY, Seki Y (2012). Biological materials: structure and mechanical properties. Progress in Materials Science. 53(1), 1-206.

17. Tanger P, Field JL, Jahn CE, DeFoort MW, Leach JE. Biomass for thermochemical conversion: targets and challenges (2013). Frontiers in plant science, 4,218.

18. Sandru O. Carbonized Chicken Feathers Better Than Carbon Nanotubes at Storing Hydrogen, The Green Optimistic 2009. http://www.greenoptimistic.com/2009/06/25/carbonized-chicken-feathers-hydrogen-storage/

19. Richard P. Wool, Erman Şenöz Hydrogen Storage on carbonised chicken feather fibres.13th Annual Green Chemistry \& Engineering Conference. University Delwar 2009.

20. Senoz E, Wool RP (. 2010). Microporous carbon-nitrogen fibers from keratin fibers by pyrolysis. Journal of applied polymer science, 118 (3), 1752-65.

21. https://us.vwr.com/store/product/4787011/barnstead-thermolyne-ashing-furnaces-type-6000-and-type-30400thermo-scientific

22. Gao L, Hu H, Sui X, Chen C, Chen Q. (2014) One for two: Conversion of waste chicken feathers to carbon microspheres and (NH4) HCO3. Environmental science \& technology. 12; 48(11), 6500-7.

23. Brunauer, S., Emmett, P.H. and Teller, E (1938).Adsorption of gases in multimolecular layers. Journal of the American chemical society, 60(2), 309-319. 